\title{
Estimation of successive coseismic vertical offsets using coeval sedimentary events - application to the southwestern limit of the Sea of Marmara's Central Basin (North Anatolian Fault)
}

\author{
C. Beck ${ }^{1}$, C. Campos $^{1,2}$, K. K. Eriş ${ }^{3}$, N. Çağatay ${ }^{4}$, B. Mercier de Lepinay ${ }^{5}$, and F. Jouanne ${ }^{1}$ \\ ${ }^{1}$ Laboratoire ISTerre, UMR CNRS 5275, Université de Savoie/Grenoble-Alpes University, 73376 Le Bourget du Lac, France \\ ${ }^{2}$ Departamento de Ciencias de la Tierra, Universidad Simón Bolívar, Sartenejas, Baruta, Venezuela \\ ${ }^{3}$ Firat University Faculty of Engineering Geology Department, 23100, Elazı ̆, Turkey \\ ${ }^{4}$ Istanbul Technical University EMCOL, 34469, Faculty of Mining Ayazağa, İstanbul, Turkey \\ ${ }^{5}$ Geoazur, UMR CNRS 6526, Université de Nice-Sophia-Antipolis, 06560 Valbonne, France
}

Correspondence to: C. Beck (beck@univ-savoie.fr)

Received: 27 January 2014 - Published in Nat. Hazards Earth Syst. Sci. Discuss.: 6 June 2014

Revised: 29 October 2014 - Accepted: 21 December 2014 - Published: 4 February 2015

\begin{abstract}
In the deep part of the Sea of Marmara (Turkey), the sedimentation developing upon the North Anatolian Fault is strongly influenced by the associated seismic activity, through gravity reworking (fluidized landslides) and tsunamis. Specific layers (homogenites + turbidites, $\mathrm{HmTu}$ ), representing individual sedimentary events, have been characterized along three giant piston cores retrieved from the Çinarcik and Central (or Orta) basins. Pre-Holocene, nonmarine sediments, were analyzed, representing the last 12 $17 \mathrm{kyr}$ BP (before present). For a $2 \mathrm{kyr}$ long interval, 11 events could be precisely correlated on both sides of the Central Basin's southwestern scarp. For each of them, based on the specific depositional process, the thickness difference between the two sites was considered as a direct estimation of the vertical component of a coeval coseismic offset. The homogenite (upper) component accounts for the major part of the thickness difference (ranging from 36 to $144 \mathrm{~cm}$ ). These offsets were considered as likely representing dominantly vertical throws, along the transtensional southwestern boundary of the inner, pull-apart Central Basin. In terms of natural hazards, further investigations on this local behavior should rather be directed to tsunami genesis.
\end{abstract}

\section{Introduction}

Since several decades, sedimentary archives, either marine or lacustrine, have been explored as potential paleoseismic records, beside previously well-developed terrestrial approaches (McCalpin, 2009). For the subaqueous records, two major groups of effects can be detected and analyzed: (i) in situ post-depositional disturbances (e.g., Sims, 1975; Marco and Agnon, 1995; Ken-Tor et al., 2001; Rodriguez-Pascua et al., 2002, 2003), and (ii) gravity-driven reworking and resettling of large masses of unconsolidated sediments (e.g., Adams, 1990; Strasser et al., 2006).

Two major questions arise for both groups: (1) how to ensure the earthquake-triggering, (2) how to identify the responsible active structure(s). For in situ disturbances, the first problem is generally solved; in particular, it benefits from analogical and/or numerical modeling (e.g., Moretti et al., 1999; Wetzler et al., 2010). For redepositional processes - which are envisaged in the present work - several recent catastrophic events could be surveyed shortly after their occurrence (Thunell et al., 1999; McHugh et al., 2011; Lorenzoni et al., 2012); the results reinforced the earthquakeinduced interpretation proposed for some "homogenite-type" layers (Chapron et al., 1999; Beck et al., 2007).

For historical and older events, the seismic origin of a specific layer can be established as follows: 
- directly, using intrinsic characteristics such as texture, origin of components, overall geometry, etc. (see in references Beck, 2009; Beck et al., 2007);

- indirectly, (i) on the basis of correlations with reported seismic events (for historical seismicity) (e.g., Siegenthaler et al., 1987; Piper et al., 1992; Chapron et al., 1999; Goldfinger et al., 2007; Beck et al., 2012) and (ii) when detecting the same paleoevent in a large area independently from local setting (e.g., variable slope dip). This second approach is especially used for deep structures, as subduction, (e.g., Goldfinger et al., 2007; Gracia et al., 2010; Moernaut, 2011; Pouderoux et al., 2012) and also, in some cases, for surface-reaching major faults (e.g., Goldfinger et al., 2007);

- combining both types of arguments.

Direct relationships between an active structure and earthquake-induced sedimentary events are investigated for active faults reaching a sediment-water interface (sea or lake bottoms), through high-resolution imagery or/and coring. This favorable setting recently allowed detailed analyses of fault activity (offsets, slip rates) through adjacent sedimentation (Carrillo et al., 2006, 2008; Bull et al., 2006; Barnes and Pondard, 2010; Beck et al., 2012). The here-presented work was dedicated to one of these cases: the deep part of the Sea of Marmara (northwestern Turkey) developed along the North Anatolian Fault.

As the here-used sedimentological tools and approaches have been previously published (Polonia et al., 2004; Sari and Çağatay, 2006; McHugh et al., 2006; Beck et al., 2007, 2012; Nakajima and Kanai, 2000; Uçarkuş, 2010; Çağatay et al., 2012; Drab et al., 2012; Eriş et al., 2012; Campos et al., 2013) only results (data and interpretations) implying paleoseismological aspects will be envisaged. Detailed sedimentological aspects may be consulted in the above-mentioned publications.

\section{Tectonic context and data acquisition}

Being the gateway between the Black Sea and the Aegean Sea, with narrow shallow connections (Fig. 1), the Sea of Marmara has become the focus of paleoenvironmental investigations (Çağatay et al., 2009; McHugh et al., 2006). In particular, late Quaternary climatic cycles, and especially associated sea level changes, left a strong sedimentary imprint in shallow parts as well as in deep basins (Çağatay et al., 2000; Major et al., 2006; Vidal et al., 2010, etc.). Different hypotheses (including catastrophic flooding) have been proposed for the last "reconnection" of the three realms through the Bosphorus and Dardanelles (Çanakkale Straits) sills (Ryan et al., 1997, 1999; Aksu et al., 1999, Eriş et al., 2007, etc.). For our purpose, the age of the last nonmarine to marine shift of the Sea of Marmara is a key point: (i) for the chronological frame of recent seismotectonic activity; and (ii) for the change of volume, composition, and behavior of remobilized sediments (impact of water density and circulation).

\subsection{Structural setting and recent seismic activity}

The whole circum-Mediterranean areas represent complex and active plate boundaries where subduction and faulting are responsible for high seismic hazards (Ambraseys, 2009). Among microplates located between the two major Eurasian and African plates, the Anatolian Plate (Fig. 1 insert; McClusky et al., 2000; Flerit et al., 2003; Reilinger et al., 2006) is highly investigated as its boundaries have produced catastrophic earthquakes and represent a high permanent seismic risk. More precisely, the northern limit of the Anatolian Plate corresponds to the - right lateral strike slip - North Anatolian Fault (NAF in the following), of which the northern branch follows the Sea of Marmara from the Izmit Gulf (east) to the Aegean Sea (west) (Barka and Kadinsky-Cade, 1988; Armijo et al., 2002; Polonia et al., 2004; McNeill et al., 2004; Seeber et al., 2006; Gasperini et al., 2011; Kurt et al., 2013, etc.). Besides the dominant strike-slip displacement, the importance of normal faulting and fast subsidence has been underlined, especially for the Central and Çinarcik basins (Cormier et al., 2006; Carton et al., 2007).

The migration of historical catastrophic ruptures along the NAF has been intensively investigated aiming to understand past and present stress distribution, and to improve seismic risk assessment (Toksöz et al., 1979; Ambraseys and Jackson, 2000; Ambraseys, 2002; Hubert-Ferrari et al., 2002; Altunel et al., 2004; Aksoy et al., 2010; Fraser et al., 2010; Uçarkuş et al., 2011; Meghraoui et al., 2012, etc.). In particular, two destructive ruptured sections have been surveyed (offset and length) respectively west and east of the Sea of Marmara: (1) the $M_{\mathrm{w}} 7.41912$ Ganos event, and (2) the $M_{\mathrm{w}} 7.41999$ Izmit event. As the deep basins of the Sea of Marmara are bounded or crosscut by the NAF (Fig. 1), several offshore surveys have been dedicated to analyze its submerged section. Morphological and sedimentary impacts of major recent earthquakes have been searched using seismic reflection with different resolutions and penetrations, multibeam and side scan sonar, different types of coring, and remote operating vehicles (ROV) (Armijo et al., 2005). The different results concern (1) deep fluids expulsion related to seismotectonic activity (Géli et al., 2008; Tary et al., 2012; Burnard et al., 2012, etc.); (2) mass wasting and creep (Zitter et al., 2012; Shillington et al., 2012); (3) deep sedimentation specificities (McHugh et al., 2006; Sari and Çağatay, 2006; Beck et al., 2007; Çağatay et al., 2012; Drab et al., 2012); and (4) detection and dating of historical coseismic scarps (Armijo et al., 2005; Uçarkuş, 2010). Historical tsunami reports and modeling (Altinok et al., 2011; Hébert et al., 2005) complete these different data, taking into account the fact that these phenomena are not systematically associated with 


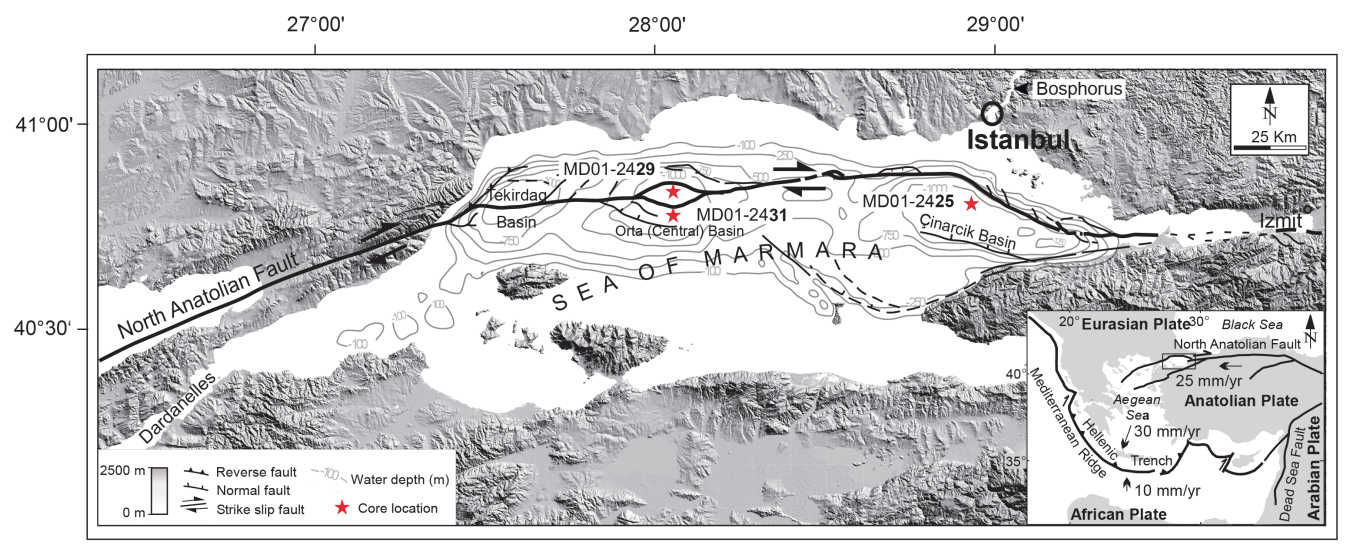

Figure 1. The Sea of Marmara and the North Anatolian Fault: simplified bathymetry and active structures. Location of analyzed core. NAF geometry simplified from Armijo et al. (2002, 2005), and GPS kinematics from McClusky et al. (2000) and Reilinger et al. (2006).

earthquakes (Hornbach et al., 2010). Small size lacustrine basins aligned along the NAF east of Izmit have also been studied for paleoseismicity (Avşar, 2013).

The Sea of Marmara and, especially, its deep basins represent a favorable setting for the search of past seismic activity and, in general, an essential data source for regional seismic hazards estimation (cf. Armijo et al., 2005). In the following, we will focus on the Central Basin's recent sedimentary fills and additional data on the Çinarcik Basin, aiming (1) to reconstruct a succession of earthquake-induced sedimentary "events" during the pre-Holocene infilling, and (2) to use part of this succession to analyze the activity of the fault zone corresponding to the southern limit of the "inner" Central Basin (as named by Uçarkuş, 2010).

\subsection{Data acquisition and processing}

The here-used data were collected during two cruises: (1) the MARMACORE survey (on R/V MARION-DUFRESNE), (2) the MARMARASCARPS survey (on R/V ATALANTE). Three types of cores were retrieved: giant gravity piston cores (CALYPSO device), classical Kullenberg-type cores, and very short cores $(35 \mathrm{~cm})$ visually picked using the VICTOR ROV. The processing of these two sets of core was achieved in L. Drab's and G. Uçarcus' PhD theses, and yielded dense paleoseismic information (Uçarkuş, 2010; Drab et al., 2012). In parallel, high-resolution $(3.5 \mathrm{kHz})$ seismic profiles were acquired, and a complete survey with the VICTOR ROV was dedicated to a high-precision multibeam bathymetric mapping of different deep scarps (Armijo et al., 2005; Uçarkuş, 2010). A preliminary analysis of seven CALYPSO cores (with length ranging from 22 to $37 \mathrm{~m}$ ) and $3.5 \mathrm{kHz}$ imagery has been achieved (Beck et al., 2007). Three of them (MD01-2425 in Çinarcik Basin, MD01-2429 and MD01-2431 in Central Basin; location in Fig. 1) were chosen for later detailed laboratory sedimentological analyses on split cores (Eriş et al., 2012, and this work):
- sediment composition: microscopic observations, carbon and carbonate contents (LOI) XRF (X-ray fluorescence) profiles in selected portions (AVAATECH instrument), and bulk magnetic content (BARTINGTON contact sensor with $5 \mathrm{~mm}$ measurement interval);

- layering and texture (grain array):

- + X-ray pictures (SCOPIX device; Migeon et al., 1998)

- + detailed grain size analysis (MALVERN Mastersizer, 2000): base-to-top paths on binary diagrams for turbidite/homogenite layers (Beck, 2009; Eriş et al., 2012), and particle shape analysis for silty-clay fraction (SYSMEX FPIA-2100 device);

- + anisotropy of magnetic susceptibility (AMS) profiles ( $2 \mathrm{~cm}$ interval) on selected portions (Campos et al., 2013), completed with anhysteretic remanent magnetization (ARM) and isothermal remanent magnetization (IRM) (AGICO MFK1-FA Kappabridge, SQUID and 2G 760R systems).

The chronology is based on AMS ${ }^{14} \mathrm{C}$ calibrated ages: previously published measurements performed at Woods Hole Oceanographic Institution (NOSAMS facility) (Beck et al., 2007), and a set of new measurements performed at CEA (French Atomic Energy Commission) Saclay (CNRS-INSU ARTEMIS facility).

\section{Recent sedimentation in the Çinarcik and Central basins of the Sea of Marmara}

Cores MD01-2425, -2429, and -2431 (locations in Fig. 1) were respectively retrieved at 1215,1230 , and $1170 \mathrm{~m}$ depths, with $31.30,37.30$, and $26.40 \mathrm{~m}$ respective lengths. They respectively represent about 17,14 , and $18 \mathrm{kyr}$ before Present of continuous deposition. The compositions, 


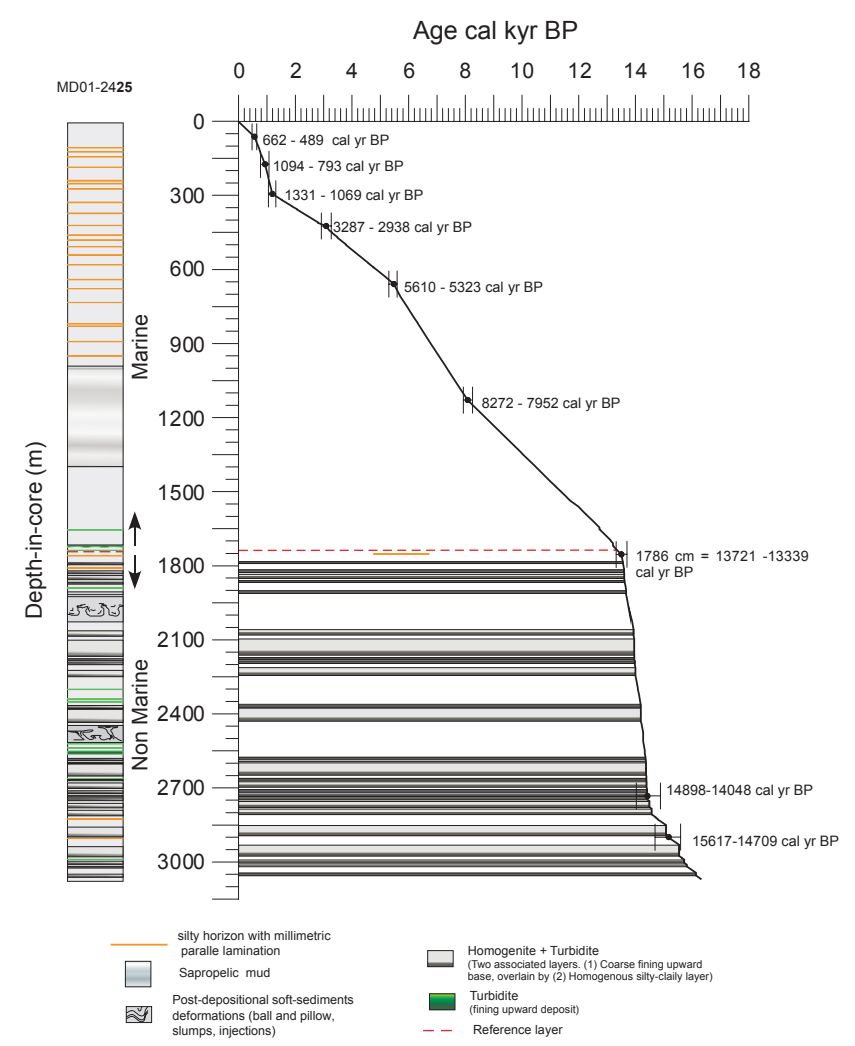

Figure 2. Age/depth curve of core MD01-2425 (Çinarcik Basin) displaying major instantaneous deposits (homogenite + turbidite). Red dashed line indicates the limit between nonmarine (below) and marine sequences (reference layer displayed in Figs. 3 and 5); pLGH: pre-late glacial homogenite (Beck et al., 2007).

layering-types, and the general chronostratigraphy, appear very similar between the three cores; therefore, we will summarize the results obtained for core MD01-2425 as a reference. They confirm and complete the investigations previously achieved by Eriş et al. (2012).

\subsection{The post-LGM succession in the Çinarcik Basin (core MD01-2425)}

Figure 2 summarizes the succession within which, especially in the lower (nonmarine) part, numerous turbidites, often associated with an overlying homogenite, are intercalated. For this reason, we will describe separately these instantaneous sedimentary "events" and the continuous ("background") slow sedimentation. A neat subdivision into two successions appears (see also Eriş et al., 2012): (1) a lower part with a mean high sedimentation rate (about $5.4 \mathrm{~mm} \mathrm{yr}^{-1}$ ) due to abundant intercalations of coarser instantaneous terrigenous inputs; and (2) an upper part with lower mean sedimentation rate $\left(1.3 \mathrm{~mm} \mathrm{yr}^{-1}\right)$ and few coarser intercalations. The limit (discussed hereafter) roughly corresponds to the transition from nonmarine (only connection with the Black Sea) to marine (connection with Aegean Sea and Black Sea) setting.
The whole core corresponds to the Late Glacial-Holocene period.

\subsubsection{Background sedimentation}

It is represented in the whole core by a hemipelagic siltyclayey mud. Although the word "hemipelagite" should be restricted to marine/oceanic deposits, we also use it for the nonmarine succession as, in both cases, it is a mixture of clayeysilty terrigenous fraction (clay minerals, quartz, plagioclase, amphibole, pyroxene, fresh micas, opaques) and planktonic biogenic or bioinduced particles (carbonate and silica: calcareous nanoplankton, diatoms). Additional authigenic particles are locally abundant (sulfides, calcite, aragonite, $\mathrm{Mn}$ oxydes).

The bulk carbonate content ranges from 8 to $10 \%$ in the upper marine part, it reaches $16 \%$ at the nonmarine/marine limit. Organic Matter (weight percentage of dried sediment) ranges from 4 to $6 \%$ in the lower part, and from 7 to $14 \%$ in the upper part. The highest values characterize the 1380 $980 \mathrm{~cm}$ so-called "sapropelic" interval. This organic matter enrichment has been previously reported in the different basins of the Sea of Marmara, and in the shallower zone between the Tekirdağ and Central basins (Çağatay et al., 2000; Reichel and Halbach, 2007; Beck et al., 2007; Vidal et al., 2010). The different ages proposed are in agreement and a 11-7.5 kyr BP period (cal ${ }^{14} \mathrm{C}$ without reservoir correction) has been attributed to this particular episode.

We include into the background sediments numerous siltysandy laminated intervals present in the upper marine part. They are $1-3 \mathrm{~cm}$ thick and display millimetric parallel planar bedding, involving subtle changes in grain size (up to very fine sand) and mineralogy of detrital components. They have been observed in the three basins (Tekirdağ, Central, Çinarcik) with identical characteristics and occurrence frequency (Beck et al., 2007). We relate these levels to in situ slight reworking by the episodic increase of bottom current velocities. A minor part of these intervals show low-angle microprogradation (flaser-bedding type) and appear associated with homogenites; thus, we included them into instantaneous gravity reworking events.

\subsubsection{Homogenites + turbidites (HmTu) occurrence}

Following the investigations of Cita and Rimoldi (1997) and Siegenthaler et al. (1987), detailed analyses and characterizations of homogenites and their association with turbidites (here labeled $\mathrm{HmTu}$ ) have been developed (references in Chapron et al., 1999; Beck et al., 2007; Campos et al., 2013); the use of these specific layers as paleoearthquake/paleotsunami indicators has been underlined. On split core surface and X-ray pictures, a series of such layers have been visually identified (Fig. 2) mostly in the nonmarine lower part of the core. With up to $1 \mathrm{~m}$ thickness, they consist of (1) a basal coarse layer with overall 
normal graded bedding, sometimes subdivided into secondorder graded episodes (similar to the classic turbidite lower term), and (2) strongly homogenous fine-grained $(2-8 \mu \mathrm{m}$ mean grain size) intervals, lacking internal variation, and displaying an anomalously high magnetic foliation. As the content and particle shapes of the homogeneous upper component are identical to what is observed in the hemipelagic mud, the AMS contrast is attributed to a particular grain array (Campos et al., 2013) and, in general, to a specific settling process. The sharp break between the two components is often preceded by a thin interval with flaser-bedding-type layering indicating a to-and-fro (oscillatory) current, and/or by a specific grain-size evolution. We interpreted this transitional interval as a consequence of oscillation of the whole water mass (seiche effect and/or reflected tsunami), thus an effect of an earthquake and/or massive subaqueous landslide.

In the upper marine part of the succession (Fig. 2), these HmTu "events" are scarce and thinner; they only display a discrete coarser layer and homogeneous mud with same texture as in the nonmarine HmTu events. Some classical turbidites were also found in core MD01-2425. We discarded them in the following, as we could not ensure their earthquake-triggering using our criteria; this choice probably minimizes the total number of inferred recorded paleoearthquakes. The contrast between the two parts of the succession (roughly between late glacial and Holocene) is a matter of debate (Beck et al., 2007). To explain the abundance of terrigenous input in the late glacial, we may envisage either higher storage of sediments in subaqueous deltas and subsequently higher potential for gravity reworking (climatic influence), or more frequent and powerful earthquakes (tectonic influence). This question has been underlined also for the post-LGM fill of large perialpine lakes (Beck et al., 1996). For the Sea of Marmara, a change in the water density vertical profile and in circulation may also account for the distribution of bedload and suspended load.

\subsubsection{The nonmarine to marine transition - age and implications}

As our work was dedicated to the lower (nonmarine) part of the cores - displaying the strongest reworking events - we investigated the nonmarine-marine transition as a chronological marker reliable for precise correlations. Due to its importance for the study of the last climatic cycle, the hydrologic evolution of the Sea of Marmara has been intensively surveyed by different authors through sedimentation. Biological, chemical, mineralogical, and isotopic proxies, have been analyzed to detect the respective influence of the Black Sea and the Aegean Sea since the Last Glacial Maximum (MIS 2) depending on their surface level (Çağatay et al., 2000; Major et al., 2006; Reichel and Halbach, 2007; Eriş et al., 2007; Vidal et al., 2010). The impact of these variations has also been investigated in shallow parts (Çağatay et al., 2003).

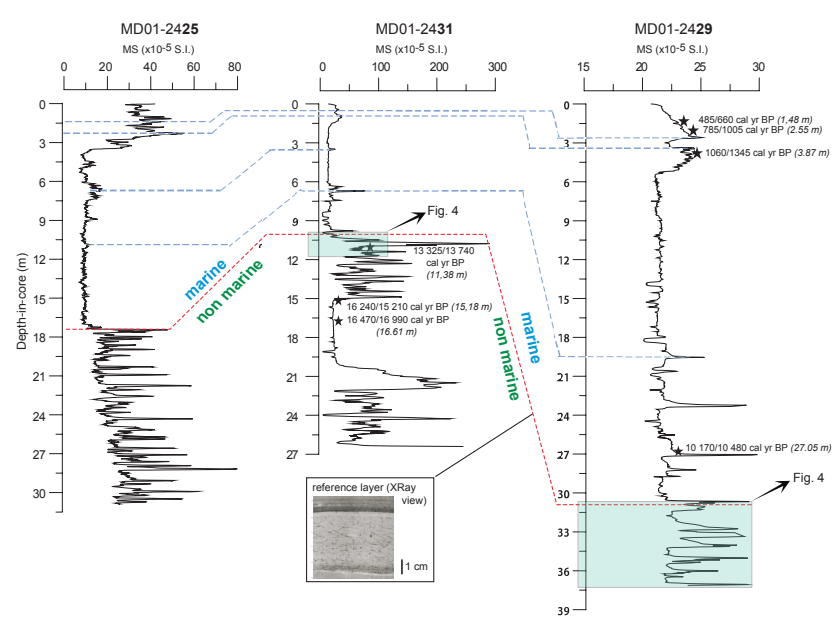

Figure 3. Chronostratigraphic correlations between the Çinarcik Basin (core MD01-2425) and the Central Basin (cores MD01-2429 and -2431). Blue rectangles correspond to close-up and detailed correlations in Fig. 5.

Based on detailed data from cores taken in the Central Basin and between the Tekirdağ and Central basins, Reichel and Halbach (2007) proposed a model of fresh water and marine water mixing. Their results fit with their detection of a calcite peak $(30 \%)$ related to authigenic precipitation and interpreted as the result of a first mixing of bottom anoxic fresh water with surface oxic marine water. According to their radiocarbon dating, this change occurred at $13 \mathrm{cal} \mathrm{kyr} \mathrm{BP} \mathrm{(be-}$ fore present). Vidal et al. (2010) concluded on a slightly different scenario: beginning with the Aegean influence at $14.7 \mathrm{cal} \mathrm{kyr} \mathrm{BP,} \mathrm{the} \mathrm{progressive} \mathrm{increase} \mathrm{of} \mathrm{the} \mathrm{mixing,} \mathrm{last-}$ ing $2 \mathrm{kyr}$, and followed at $12.8 \mathrm{cal} \mathrm{kyr} \mathrm{BP}$ by an increase of terrigenous continental organic material. They relate the latter to the beginning of Younger Dryas (YD). The calcite maximum may correspond to the end of mixing process. The end of significant Black Sea input at 11.5 cal kyr BP (Vidal et al., 2010) may correspond to the end of the calcite-rich episode. Differences may be due to data sets respectively coming from a deep basin floor (Vidal et al., 2010) and from a shallower setting between two basins (Reichel and Halbach, 2007).

In the here-studied cores, X-rays (Fig. 3 insert) allowed identifying a $2-5 \mathrm{~cm}$ thick, conspicuous layer of highly bioturbated mud, overlain by about $1 \mathrm{~cm}$ of laminated silty mud (parallel planar bedding). It is marked by an increase of finegrained plant debris, and an abrupt change in magnetic content with respect to hemipelagic intervals. It also corresponds to the last occurrence of diatom frustule fragments. A XRF chemical profile (core scanning) performed across this layer - from $40 \mathrm{~cm}$ below to $100 \mathrm{~cm}$ above - did not display any abrupt change but rather the beginning of a very progressive increase of $\mathrm{Br}, \mathrm{Mo}$, and $\mathrm{S}$, considered as a diagnostic for more-marine environment. According to our measurements, Carbonate content reaches a maximum just below this level 

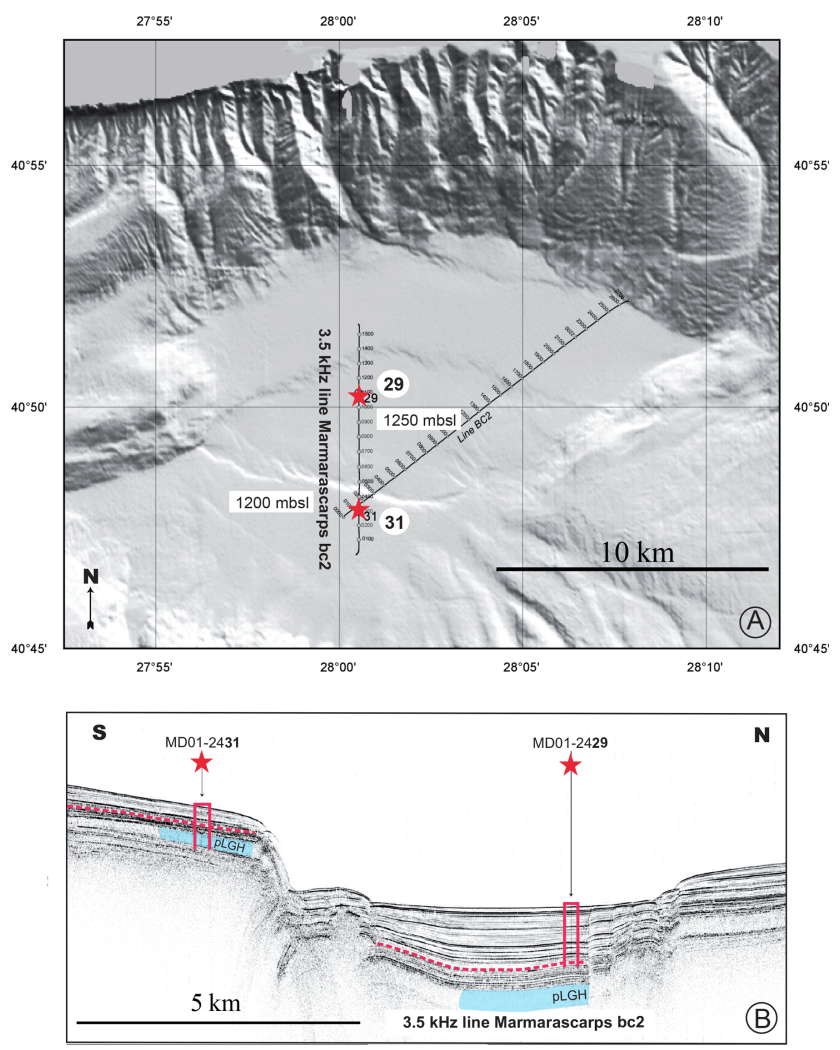

Figure 4. Detailed location of the Orta/Central Basin's long cores. (a) Bathymetry taken from Rangin et al. (2001); (b) very-highresolution seismic profile from the MARMARASCARPS survey (Armijo et al., 2005; Uçarkuş, 2010). Red dashed line indicates the limit between nonmarine (below) and marine sequences (also underlined in Figs. 3, 4 and 5).

(named "reference layer" in the following) and sharply decreases above.

Combining all published results (and our ${ }^{14} \mathrm{C}$ results) we consider our "reference layer" as the YD base and we will use, for the paleoseismic record discussed hereafter, a $12.8 \mathrm{cal}$ kyr BP age, being this assumption questionable and approximate.

\subsection{Correlations between the Çinarcik and Central basins, and inside the Central Basin}

In order to extract a paleoseismic record through $\mathrm{HmTu}$ events, we checked (1) a regional correlation between the Central and Çinarcik basins (MD01-2425, -2429, and -2431; see also Beck et al., 2007; Eriş et al., 2012), and (2) a more localized correlation on both sides of the active scarp bounding the inner Central Basin on its southwestern side (Fig. 4). The catastrophic pre-late glacial event (pLGH in Fig. 4) detected on high-resolution profiles and cored at site MD012431 (Beck et al., 2007) was not reached at site MD01-2425.

Figure 3 displays the general correlation on the basis of high-resolution bulk magnetic susceptibility (MS) profiles.
All other measured parameters (not added here: mineralogy and chemistry, biogenic and bioinduced markers; Campos, 2014), ${ }^{14} \mathrm{C}$ ages, and the nonmarine to marine change horizon, complete the correlation criteria. For the same late glacial part of the succession (from about $16 \mathrm{kyr}$ BP to the marine/nonmarine limit (our "reference layer"); Figs. 2, 3), HmTu appear more frequent in core MD01-2425 (Çinarcik Basin) than in core MD01-2431 (Central Basin). This difference is also mentioned by Drab et al. (2012) for the last $2.5 \mathrm{kyr}$ BP (marine section); based on a precise chronology on short piston cores, these authors could propose several event-by-event correlations and their attribution to historical earthquakes.

Despite the X-ray's resolution and sampling intervals of the different logs, we could not ensure an "event-by-event" correlation between the Çinarcik and Central basins along the whole nonmarine section. Conversely, an event-by-event correlation within the Central Basin could be proposed for the last $2 \mathrm{kyr}$ preceding the main hydrologic change (blue rectangles in Fig. 3). Figure 4a and b shows the location of cores MD01-2429 and MD01-2431 and the overall correlations previously proposed by Beck et al. (2007) and Eriş et al. (2012) based on a $3.5 \mathrm{kHz}$ seismic reflection profile.

\subsection{Choice of the pre-Holocene - nonmarine - succession to analyze the southwestern limit of the inner Central Basin}

Both on giant piston cores (direct view, X-ray pictures) and on $3.5 \mathrm{kHz}$ seismic reflection profiles (Beck et al., 2007), the thickest and well-defined homogenites + turbidites appear in the pre-Holocene part of the retrieved succession (Fig. 2). Furthermore, our preliminary analysis of the two cores bounding the southwestern Central Basin (MD01-2431 and MD01-2429) demonstrated that, for this period, the total "overthickness" in the deep part (inner Central Basin), corresponds to the sum of overthicknesses of separate homogenites (homogeneous upper component of $\mathrm{HmTu}$ ). Furthermore, changes in HmTu thickness are abrupt and correspond exactly to the rupture zone. For the Holocene, or the last millennia, recent sedimentological investigations with paleoseismic purpose have been conducted by Drab et al. (2012) and McHugh et al. (2014). For these different reasons, to discuss relationships between scarp genesis and sealing-off deposition, we focused on the pre-Holocene part along the southwestern boundary of the inner Central Basin.

In the following, site MD01-2431 will be considered as a "footwall" setting. Although the inner Central Basin appears rather symmetric (Fig. 4), with site MD01-2429 located in the middle, we will refer to is as "hanging wall". 


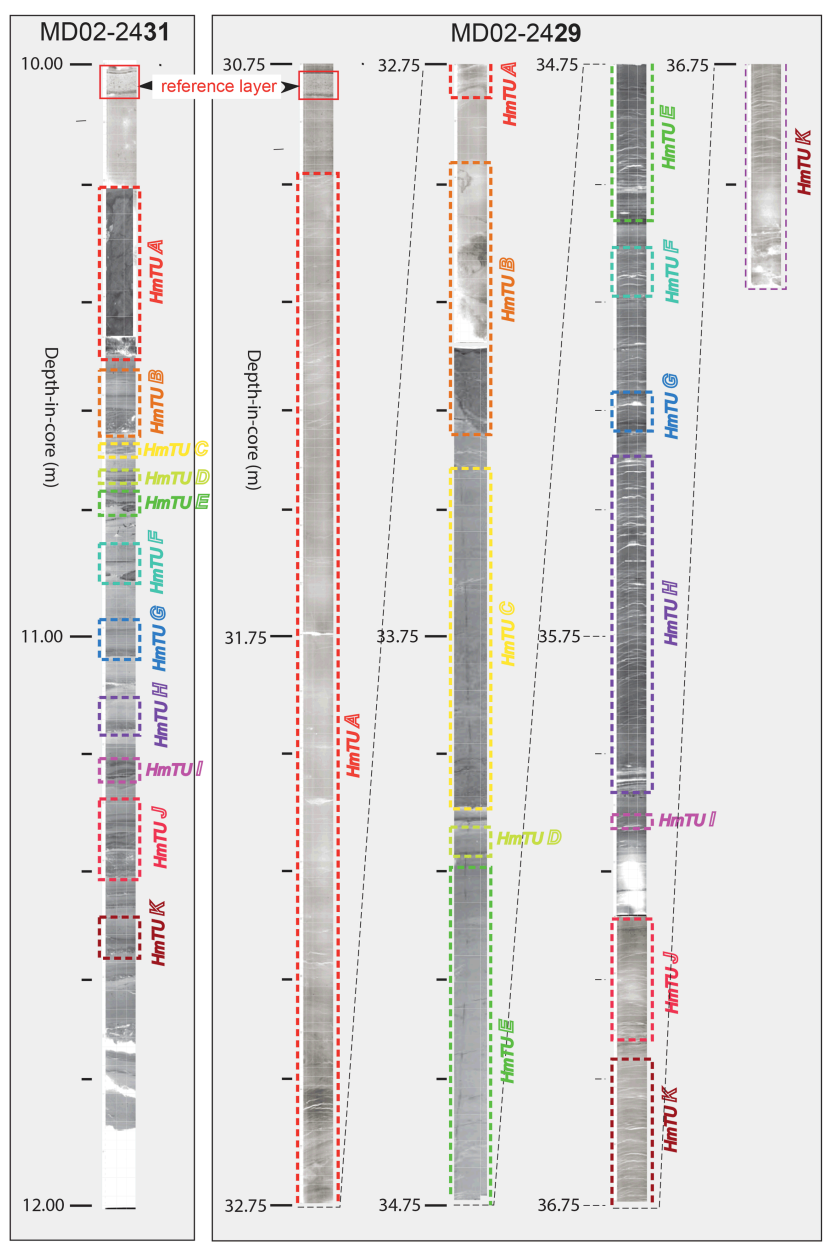

Figure 5. X-ray close up of two synchronous portions of cores MD01-2429 and MD01-2431, displaying individually correlated sedimentary events (homogenite + turbidite).

\subsection{Pre-Holocene sedimentary events in the Central Basin as responsible for coseismic scarps "sealing off"}

\subsubsection{Impact of HmTu on bottom morphology}

As underlined by different authors (see references in Chapron et al., 1999), the main characteristic of homogenites is a systematic settling in deepest areas, in marine basins as well as in large lacustrine basins. This particular depositional process results in partly or totally "erasing" (or "sealing off") existing bottom reliefs (cf. Cita and Rimoldi, 1997). This configuration is quite the opposite of the "draping" one which characterizes deep hemipelagic accumulations. As homogenite occurrences need the combination of gravity reworking (resuspension) and tsunami effect (especially in case of reflected tsunamis vs. seiche effect in closed basins), this process may also withdraw a bottom relief created simultaneously with the sedimentary reworking, such as the front of a landslide or a coseismic fault scarp. These direct rela-

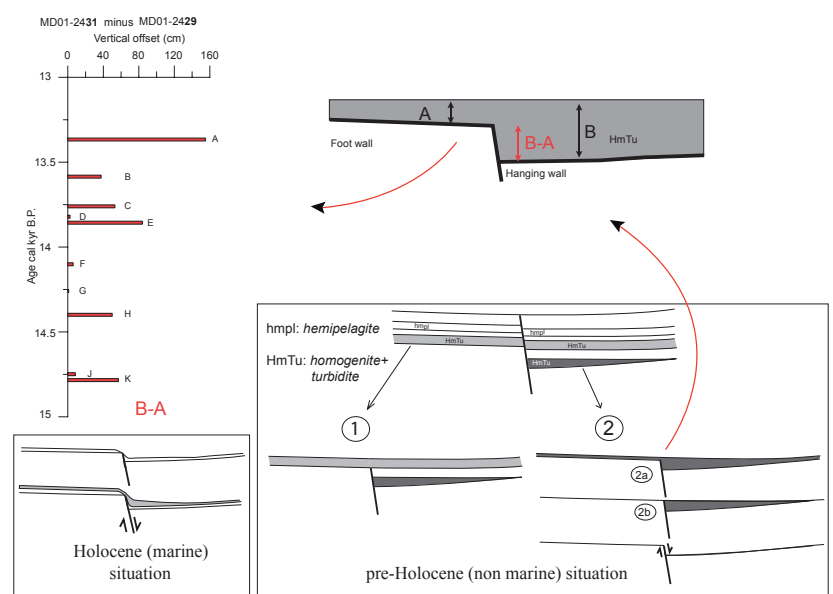

Figure 6. Successive inferred individual coseismic offsets deduced from $\mathrm{HmTu}$ thickness differences (insert sketch modified from Beck et al., 2012).

tionships (time and location) between a submarine coseismic scarp and synchronous specific layers have been proposed by Barnes and Pondard (2010) and Beck et al. (2012), and have been used (1) to decipher coseismic rupturing from creeping, and (2) to estimate the vertical component of coseismic offsets.

Concerning the Sea of Marmara's Central Basin, we have considered the pre-Holocene distribution of the different types of layers (Fig. 5), assuming that the "reference" layer was horizontal and continuous at its depositional time. Thus, all events detected below the latter, appear to have totally compensated the scarp separating site MD01-2431 from site MD01-2429. The situation appears quite similar to the one described by Beck at al. (2012) in the Lesser Antilles Arc (case 2a; insert in Fig. 6).

\subsection{Use of event-by-event thickness differences as indicators of coseismic offsets' vertical components}

The two analyzed sites are on both sides of the southern limit of the "inner" Central Basin (Fig. 4a), with a small relative depth difference ( $50 \mathrm{~m}$ at $1200 \mathrm{~m}$ b.s.1.). Figure $4 \mathrm{~b}$ displays their position with respect to a major active fault scarp. Our own previous observations of these cores had demonstrated that the high difference of mean sedimentation rates between the two sites (Fig. 4b) was essentially due to the difference of instantaneous sedimentary event thicknesses (Beck et al., 2007). Nevertheless, we could not establish precise correlations (especially event-by-event) as later done by Drab et al. (2012) for the 2 late millennia using shorter gravity cores.

A new, complete, detailed study of the nonmarine section where major homogenites and turbidites had been identified was performed (Campos, 2014). The discovery and the multicriteria characterization of a specific layer allowed defining a "reference" thin layer (Fig. 3) which is independent from 
any earthquake-/landslide-triggered sedimentary event and was also recognized in Çinarcik Basin's long core, rather indicating a general paleoenvironmental event (chemical, mineralogical, and biological modification). Starting from this level, a layer-by-layer correlation was established downcore.

This proposed event-by-event correlation (Fig. 5) was strengthened by (i) precise delimitation of the hemipelagic intervals, with same thicknesses, and (ii) similarities of subdivisions within $\mathrm{HmTu}$ composite layers. The correlation could be achieved for a $2 \mathrm{~m}$ succession in core MD012431 , which appears equivalent to a $6.2 \mathrm{~m}$ succession in core MD01-2429, both successions representing a 2 kyr duration. Eleven HmTu events account for the difference. For the thickest ones (HmTu A, C, E, H, K) the homogeneous component accounts for about $90 \%$ of the thickness increase in the deeper site. In the Lesser Antilles Arc, Beck et al. (2012) described an active normal fault upon which the sea floor is maintained flat and horizontal, being each coseismic offset quite exactly compensated by a coeval silty-sandy homogenite (Fig. 6 insert, case 2b). We tentatively applied their $2 b$ model to the Central Basin events. Of the 11 events, 10 were plotted on an age vs. thickness difference log (Fig. 6). Six of them led to significant values between 40 and $160 \mathrm{~cm}$. Although the investigated sediments are recent with a reduced depth in core, a possible compaction effect has to be discussed as (i) it concerns mainly clayey-silty material, and (ii) the thickness of the homogenite term is up to 10 times higher on the hanging wall with respect to the footwall. Based on this differential compaction, a $10 \%$ maximum estimate is thus proposed for a correction of the thickness difference (leading to $44-178 \mathrm{~cm}$ ).

\subsection{Time distribution of HmTu events}

We estimated the time distribution of instantaneous sedimentary events $(\mathrm{HmTu})$ using hemipelagic interval thickness, as successfully done in different cases by different authors (e.g., Adams, 1990; Goldfinger et al., 2007; Pouderoux et al., 2012). Two causes of imprecision or error have to be discussed: general chronology (14C), and erosion at the base of density currents (here the basal turbidite of $\mathrm{HmTu}$ ).

Few ${ }^{14} \mathrm{C}$-dated samples (indicated in Fig. 3) could be obtained for the nonmarine section, and a chronological imprecision remained (large error interval, choice of reservoir effect, possible diagenetic effect). For our purpose (interval durations and lateral correlations) this mostly affects the position of the reference layer (see Sect. 3.2), but not the main part of the interpretation for which the time interval duration is more important than its precise chronological position.

Concerning the problem of possible erosion of hemipelagic intervals below the base of HmTu (leading to "shorter" time intervals between two events), no generalized rules are available. We here assume a direct argument and a negative one. In one of our previous investigations (Lesser Antilles Arc; Beck et al., 2012), in the upper part of à $6 \mathrm{~m}$ long piston core, $\mathrm{a}{ }^{210} \mathrm{~Pb}$ decay curve and a ${ }^{137} \mathrm{Cs}$ peak were clearly detected below a silty-sandy, $2 \mathrm{~m}$ thick, homogenite, which could be related to a recent earthquake (1974). This indicated negligible erosion with respect to the underlying hemipelagic sedimentation intervals (several centuries). However, in coastal macrotidal regimes, few millimeters thick clayey-silty layers (from suspended-load settling) are commonly preserved under up to $1.0 \mathrm{~m} \mathrm{~s}^{-1}$ tidal currents carrying sand-size particles. Their removing may occur but as mud clasts during higher energy wave effects. For the Central Basin we only observed mud clasts of hemipelagic laminated sediments as a basal component of the large pre-late glacial event $(15 \mathrm{~m}$ thick on hanging walls; Fig. 3, Beck et al. 2007), there genesis was attributed to earthquake-induced in situ microfractures.

Based on these different arguments and on direct observation of cores, we assumed negligible "depositional time missing" between two successive HmTu events.

\subsection{Estimation of corresponding paleomagnitudes}

The proposed use of HmTu to analyze subaqueous active faulting along the inner Central Basin led to estimate a set of inferred coseismic offsets, for a $2 \mathrm{kyr}$ long interval. As it is a 2-D approach, the results only concern a vertical component (cf. Figs. 4, 6). The latter may represent either the vertical component of an oblique slip displacement or a subvertical (normal here) one. West of the Central Basin, a historical scarp was observed and analyzed (Armijo et al., 2005; Uçarcuş, 2010) displaying locally low-angle dipping slickensides; this site belongs to a NAF section with dominant strike-slip behavior (submerged prolongation of the Ganos Fault). The here-studied area differs from this situation and also from the Çinarcik Basin as analyzed and modeled by Seeber et al. (2006) and Kurt et al. (2013). Otherwise, the here-analyzed site should be rather considered as a transtensional limit of a pull-apart basin (Armijo et al., 2005; Uçarcuş, 2010). Different investigations have highlighted the importance of a vertical component in the Izmit Gulf and Tekirdağ Basin (Cormier et al., 2006; Carton et al., 2007). Based on tsunami modeling applied to the Sea of Marmara, Hébert et al. (2005) conclude on the importance of the vertical offset related to faulting or to submarine landslides. In the following, we thus assumed that our estimated values represent dominant vertical throws, i.e., normal with minor lateral offsets (approximately $70^{\circ}$ pitch).

With respect to an approach in terms of paleomagnitude $\left(M_{\mathrm{w}}\right)$ of earthquakes associated with estimated offsets, additional data are needed to propose an actual, complete, paleoseismic approach: horizontal length and lower limit of rupturing. Nevertheless, we propose estimations for two inferred offset values (44 and $178 \mathrm{~cm}$; Fig. 6; with compaction effect). We consider the following:

- a $70^{\circ}$ mean fault dip as displayed by deep seismic reflection data from Laigle et al. (2008); 
- two possibilities for the sea bottom rupture horizontal length: $8 \mathrm{~km}$ if considering the total length of the SW side of the inner Central Basin "losange", or $5 \mathrm{~km}$ if considering only the eastern continuous scarp (see morphology in Fig. 4a);

- a brittle/ductile transition at two different depths following the distribution proposed by Inan et al. (2007, in Uçarkuş, 2010): 12 and $20 \mathrm{~km}$. These values respectively correspond to the western termination and the eastern half of the analyzed scarp.

We applied the Moment Magnitude Calculator software (Jet Propulsion Laboratory and University of Southern Carolina, 2013) with two current shear modulus values. The results show $M_{\mathrm{W}}$ comprised between 5.9 and 6.6. The corresponding $M_{\mathrm{O}}$ (seismic moment) values, the fault length and the fault surface values, were plotted on two diagrams respectively from Kanamori and Anderson (1975) and Henry and Das (2001). Our results fit better with intraplate earthquake distributions and using a $8 \mathrm{~km}$ rupture length (thus the whole SW limit of the inner Central Basin).

\subsection{Recurrence time intervals for the analyzed section}

The inferred offsets were separated by variable time intervals (100-550 yr); if taking into account the 11 events, a mean $180 \mathrm{yr}$ interval is deduced. The time distribution is in agreement with previously published paleoseismic results based on sedimentary records in the same area (Beck et al., 2007; Drab et al., 2012).

In terms of paleoseismicity, our results only concern the pre-Holocene period. Regarding the thickness difference between the two sites (3 times higher on the hanging wall), there is no drastic change at the nonmarine/marine limit. For the marine (upper) part, a specific sedimentary process is still driving an overthickening on the hanging wall (inner Central Basin) but not enough to compensate the scarp as before (insert in Fig. 6, Holocene situation). The few thin homogenites + turbidites we observed cannot account for the difference. Nevertheless, the top of the marine part (partly disturbed in our giant piston cores) corresponds to a conspicuous increase in MS (Fig. 3). In a $4 \mathrm{~m}$ long piston core, taken close to site MD01-2429, Drab et al. (2012) described a set of turbidites+homogenites; the corresponding interval is approximately comprised between $2 \mathrm{kyr} \mathrm{BP}$ and present.

To explain the remaining thickness difference during the $13 \mathrm{kyr}$ BP to present period, we favor a hypothesis implying two combined mechanisms: (1) the water vertical density profile led to more hyperpycnal distribution of gravityreworked sediments, and (2) coarse material strongly decreased due to change in weathering condition. Checking this hypothesis needs further higher-resolution analysis of the sediments (especially the laminated episodes). The present day depth difference between sites MD01-2429 and MD012431 (Fig. 4a, b) - about $50 \mathrm{~m}$ - corresponds to about
$12.5 \mathrm{kyr}$. The post-"reference layer" interval (the marine part) shows a $20 \mathrm{~m}$ "additional" thickness, leading to about $70 \mathrm{~m}$ of total vertical displacement (approximately $75 \mathrm{~m}$ slip with a mean $70^{\circ}$ fault plane dip). This could correspond to a $6 \mathrm{~mm} \mathrm{yr}^{-1}$ mean normal offset component, wand its distribution into creep vs. coseismic increments has to be further discussed. Considering a relatively low number of sedimentary events in the Central Basin with respect to Tekirdağ Basin, Drab et al. (2012) underlined a different explanation, including partial creeping along the central segment. For a longer period, we observed a similar difference between the Central Basin and Çinarcik Basin, with evidence of a specific behavior at the southern limit of the former.

\section{Conclusions}

The detailed sedimentological analysis of a sedimentary accumulation bounding a subaqueous active fault confirmed the occurrence of coseismic offsets through coeval specific events and allowed estimating the vertical component of coseismic displacement. It also confirms a dominantly coseismic behavior (null or negligible creep) at least for a $2 \mathrm{kyr}$ time interval. With up to $1.8 \mathrm{~m}$ normal slip values, added to local structural and seismological data, this archive led us to propose paleomagnitude values $\left(M_{\mathrm{W}}\right.$ between 5.9 and 6.6). This final estimation - a corollary approach with respect to the sedimentological study - is an additional matter of testing the values of throw (realistic or not) rather than an assessment in terms of regional seismic hazards, as our work concerns a localized particular segment. In terms of natural hazards, further prolongation or these results should be directed towards tsunami genesis risk estimation, as previously modeled and discussed by Hébert et al. (2005).

Acknowledgements. The presented investigations were possible thanks to CNRS-INSU funding through ISTerre Laboratory and the Universe Sciences Observatory of Grenoble/OSUG. CNRS-INSU is acknowledged for the access to ARTEMIS national AMS radiocarbon measurement facilities. C. Campos' $\mathrm{PhD}$ thesis and stay at the ISTerre Laboratory were funded through Venezuela's FUNDAYACUCHO grant no. 20093262. We thank Anne-Lise Develle (EDYTEM Laboratory) for performing the XRF profiles and help with their interpretation. The authors are grateful to Lisa McNeill and to an anonymous reviewer for their great help in clarifying and improving the interpretations and the discussion.

Edited by: R. Lasaponara

Reviewed by: L. McNeill and one anonymous referee 


\section{References}

Adams, J.: Paleoseismicity of the Cascadian subduction zone: evidence from turbidites off the Oregon-Washington margin, Tectonics, 9, 569-583, 1990.

Aksoy, M. E., Meghraoui, M., Vallee, M., Cakir, Z.: Rupture characteristics of the A.D. 1912 Murefte (Ganos) earthquake segment of the North Anatolian fault (western Turkey), Geology, 38, 991994, doi:10.1130/G13447.1, 2010.

Aksu, A. E., Hiscott, R. N., and Yasar, D.: Oscillating Quaternary water levels of the Marmara Sea and vigorous outflow into the Aegean Sea from the Marmara Sea-Black Sea drainage corridor, Mar. Geol., 153, 275-302, 1999.

Altinok, Y., Alpar, B., Özer, N., and Aykurt, H.: Revision of the tsunami catalogue affecting Turkish coasts and surrounding regions, Nat. Hazards Earth Syst. Sci., 11, 273-291, doi:10.5194/nhess-11-273-2011, 2011.

Altunel, E., Meghraoui, M., Akyüz, H. S., and Dikbas, A.: Characteristics of the 1912 coseismic rupture along the North Anatolian Fault Zone (Turkey): implications for the expected Marmara earthquake, Terra Nova, 16, 198-204, 2004.

Ambraseys, N. N.: The seismic activity in the Marmara Sea region over the last 704 years, Bull. Seismol. Soc. Am., 92, 1-18, 2002.

Ambraseys, N. N.: Earthquakes in the Mediterranean and Middle East: A Multidisciplinary Study of Seismicity up to 1900 , 947 pp., Cambridge University Press, Cambridge, UK, 2009.

Ambraseys, N. N. and Jackson, J. A.: Seismicity of the Sea of Marmara (Turkey) since 1500, Geophys. J. Int., 141, F1-F6, 2000.

Armijo, R., Meyer, B., Navarro, S., King, G. C. P., Barka, A. A.: Asymmetric slip partitioning in the Sea of Marmara pull-apart: a clue to propagation processes of theNorth Anatolian Fault?, Terra Nova, 14, 80-86, 2002.

Armijo, R., Pondard, N., Meyer, B., Uçarkus, G., Mercier de Lépinay, B., Malavieille, J., Dominguez, S., Gutscher, M.-A., Schmidt, S., Beck, C., Çagatay, N., Çakir, Z., Imren, C., Eriş, K., Natalin, B., Özalaybey, S., Tolun, L., Lefèvre, I., Seeber, L., Gasperini, L., Rangin, C., Emre, O., Sarikavak, K.: Submarine fault scarps in the Sea of Marmara pull-apart (North Anatolian Fault): Implications for seismic hazard in Istanbul, Geochem. Geophys. Geosyst., 6, Q06009, doi:10.1029/2004GC000896, 2005.

Avşar, U.: Lacustrine paleoseismic records from the North Anatolian Fault, Turkey. PhD Thesis memoir, University of Ghent, 209 pp., 2013.

Barka, A. A. and Kadinsky-Cade, K.: Strike-slip fault geometry in Turkey and its influence on earthquake activity, Tectonics, 7, 663-684, 1988.

Barnes, P. M. and Pondard, N.: Derivation of direct on-fault submarine paleoearthquake records from high-resolution seismic reflection profiles: Wairau Fault, New Zealand, Geochem. Geophys. Geosyst., 11, Q11013, doi:10.1029/2010GC003254, 2010.

Beck, C.: Late Quaternary lacustrine paleo-seismic archives in north-western Alps: Examples of earthquake-origin assessment of sedimentary disturbances, Earth-Sci. Rev., 96, 327-344, 2009.

Beck, C., Manalt, F., Chapron, E., Van Rensbergen, P., De Batist, M.: Enhanced seismicity in early post-glacial period: evidences from the posy-Würm sediments of Lake Annecy, northwestern Alps, J. Geodynam., 22, 155-171, 1996.

Beck, C., Mercier de Lépinay, B., Schneider, J.-L., Cremer, M., Çağatay, N., Wendenbaum, E., Boutareaud, S., Ménot, G.,
Schmidt, S., Weber, O., Eris, K., Armijo, R., Meyer, B., Pondard, N., Gutscher, M.-A., and the MARMACORE Cruise Party, Turon, J.-L., Labeyrie, L., Cortijo, E., Gallet, Y., Bouquerel, H., Gorur, N., Gervais, A., Castera, M.-H., Londeix, L., de Rességuier, A., and Jaouen, A.: Late Quaternary co-seismic sedimentation in the Sea of Marmara's deep basins, in: "Sedimentary Records of Catastrophic Events", edited by: Bourrouilh-Le Jan, F., Beck, C., and Gorsline, D., Spec. Iss, Sediment. Geol., 199, 65-89, 2007.

Beck, C., Reyss, J.-L., Leclerc, F., Moreno, E., Feuillet, N., Barrier, L., Beauducel, F., Boudon, G., Clément, V., Deplus, C., Gallou, N., Lebrun, J.-F., Le Friant, A., Nercessian, A., Paterne, M., Pichot, T., and Vidal, C.: Identification of deep subaqueous coseismic scarps through specific coeval sedimentation in Lesser Antilles: implication for seismic hazard, Nat. Hazards Earth Syst. Sci., 12, 1755-1767, doi:10.5194/nhess-12-1755-2012, 2012.

Burnard, P., Bourlange, S., Henry, P., Géli, L., Tryon, M. D., Natalin, B., Sengör, A. M. C., Özeren, M. S., Çağatay, M. N.: Constraints on fluid origins and migratin velocities along the Marmara Main Fault (Sea of Marmara, Turkey) using helium isotopes, Earth Planet. Sci. Lett., 341/344, 68-78, 2012.

Bull, J. M., Barnes, P. M., Lamarche, G., Sanderson, D. J., Cowie, P., Taylor, S. K., and Dix, J. K.: High-resolution record of displacement accumulation on an active normal fault: implications for models of slip accumulation during repeated earthquakes, J. Struct. Geol., 28, 1146-1166, 2006.

Çağatay, M. N., Görür, N., Algan, O., Eastoe, C., Tchapalyga, A., Ongan, D., Kuhn, T., and Kuşçu, I.: Late Glacial-Holocene palaeoceanography of the Sea of Marmara: timing of connections with the Mediterranean and the Black Seas, Mar. Geol., 167, 191-206, 2000.

Çağatay, M. N., Görür, N., Polonia, A., Demirbağ, E., Sakinç, M., Cormier, M.-H., Capotondi, L., McHugh, C., Emre, Ö., and Eriş, $\mathrm{K}$.: Sea level changes and depositional environments in the Ïzmit Gulf, eastern Marmara Sea, during the Late Glacial-Holocene period, Mar. Geol., 202, 159-173, 2003.

Çağatay, M. N., Eriş, K., Ryan, W. B. F., Sancar, Ü., Polonia, A., Akçer, S., Biltekin, D., Gasperini, L., Görür, N., Lericolais, G., and Bard, E.: Late Pleistocene-Holocene evolution of the northern shelf of the Sea of Marmara, Mar. Geol., 265, 87-100, 2009.

Çağatay, N., Erel, L., Bellucci, L. G., Polonia, A., Gasperini, L., Eriş, K. K., Sancar, Ü., Biltekin, D., Uçarkuş, G., Ulgen, Ü. B., and Damci, E.: Sedimentary earthquake records in the İzmit Gulf, Sea of Marmara, Turkey, Sediment. Geol., 282, 347-359, 2012.

Campos, C.: Comparative study of co-seismic sedimentation in two tectonically active areas: the Sea of Marmara and the Gulf of Corinth. Methodological developments, implication for seismic hazards assessment, PhD Thesis Memoir, Grenoble University, 248 pp., 2014.

Campos, C., Beck, C. Crouzet, C., Demory, F., Van Welden, A., and Eris, K.,: Deciphering hemipelagites from homogenites through Magnetic Susceptibility Anisotropy. Paleoseismic implications (Sea of Marmara and Gulf of Corinth), Sediment. Geol., 292, 1-14, 2013.

Carrillo, E., Audemard, F., Beck, C., Cousin, M., Jouanne, F., Cano, V., Castilla, R., Melo, L., and Villemin, T.: A Late Pleistocene natural seismograph along the Boconò Fault (Mérida Andes, 
Venezuela): the moraine-dammed Los Zerpa palæo-lake, Bull. French Geol. Soc., 177, 3-17, 2006.

Carrillo, E., Beck, C., Audemard, F.A., Moreno, E., Ollarves, R.: Disentangling Late Quaternary climatic and seismo-tectonic controls on Lake Mucubají sedimentation (Mérida Andes, Venezuela), in:"Lake systems: sedimentary archives of climate change and tectonic", edited by: De Batist, M. and Chapron, E., Palaeogeogr. Palaeoclim. Palaeoecol., 259, 284-300, 2008.

Carton, H., Sing, S. C., Hirn, A., Bazin, S., de Voogd, B., Vigner, A., Ricolleau, A., Cetin, S., Oçakoğlu, N., Karakoç, F., and Sevilgen, V.: Seismic imaging of the three-dimensional architecture of the Çinarcik Basin along the North Anatolian Fault, J. Geophys. Res., 112, B060101, doi:10.1029/2006JB004548, 2007.

Chapron, E., Beck, C., Pourchet, M., and Deconinck, J.-F.: 1822 earthquake-triggered homogenite in Lake Le Bourget (NW Alps), Terra Nova, 11, 86-92, 1999.

Cita, M. B. and Rimoldi, B.: Geological and geophysical evidence for a Holocene tsunami deposit in the eastern Mediterranean deep-sea record, J. Geodynam., 24, 293-304, 1997.

Cormier, M.-H., Seeber, L., McHugh, C. M. G., Polonia, A., Çă̆atay, M. N., Emre, O., Gasperini, L., Görür, N., Bortoluzzi, G., Bonatti, E., Ryan, W. B. F., and Newman, K. R.: The North Anatolian fault in the Gulf of Izmit (Turkey): Rapid vertical motion in response to minor bends of a nonvertical continental transform, J. Geophys. Res., 111, B04102, doi:10.1029/2005JB003633, 2006.

Drab, L., Hubert Ferrari, A., Schmidt, S., and Martinez, P.: The earthquake sedimentary record in the western part of the Sea of Marmara, Turkey, Nat. Hazards Earth Syst. Sci., 12, 1235-1254, doi:10.5194/nhess-12-1235-2012, 2012.

Eriş K. K., Ryan, W. B. F., Çağatay, N., Sancar, U., Lericolais, G., Menot, G., and Bard, E.: The timing and evolution of the postglacial transgression across the Sea of Marmara shelf south of Istanbul, Mar. Geol., 243, 57-76, 2007.

Eriş, K., Çağatay, N. Beck, C., Mercier de Lepinay, B., and Campos, C.: Late-Pleistocene to Holocene sedimentary fills of the Çınarc1k Basin of the Sea of Marmara, Sediment. Geol., 281, 151-165, 2012.

Flerit, F., Armijo, R., King, G. C. P., Meyer, B., and Barka, E.: Slip partitioning in the Sea of Marmara pull-apart determined from GPS velocity vectors, Geophys. J. Int., 154, 1-7, 2003.

Fraser, J., Vanneste, K., and Hubert-Ferrari, A.: Recent behaviour of the North Anatolian Fault: insights from an integrated paleoseismological data set, J. Geophys. Res., 115, 1-27, doi:10/1029/JB006982, 2010.

Gasperini, L., Polonia, A., Çağatay, M. N., Bortoluzzi, G., and Ferrante, V.: Geological slip rates along the North Anatolian Fault in the Marmara Sea, Tectonics, 30, TC6001, doi:10.1029/2011TC002906, 2011.

Géli, L., Henry, P., Andre, C., Zitter, T., Çağatay, N., Mercier de Lepinay, B., LePichon, X., Sengor, A. M. D., Gorur, N., Natalin, B., Ucarkus, G., Ozeren, S., Volker, D., Gasperini, L., Bourlanger S., and the MarNaut Scientific Party: Gas emissions and active tectonics within the submerged section of the North Anatolia Fault zone in the Sea of Marmara, Earth Planet. Sci. Lett., 274, 34-39, 2008.

Gracia, E., Vizcaino, A., Escutia, C., Asioi, A., Rodes, A., Pallas, R., Garcia-Orellana, J. Lebreiro, S., Goldfinger, C.: Holocene earthquake record offshore Portugal (SW Iberia): testing tur- bidite paleoseismology in a slow-convergence margin, Quaternary Sci. Rev., 29, 1156-1172, 2010.

Goldfinger, C., Morey, A. E., Nelson, C. H., Gutierez-Pastor, J., Johnson, J. E., Karabanov, E., Eriksson, A., and shipboard scientific party: Rupture lengths and temporal history of significant earthquakes on the offshore and north coast segments of the Northern San Andreas Fault based on turbidite stratigraphy, Earth Planet. Sci. Lett., 254, 9-27, 2007.

Hébert, H., Schindelé, F., Altinok, Y., Alpar, B., and Gaziogluc, C.,: Tsunami hazard in the Marmara Sea (Turkey): a numerical approach to discuss active faulting and impact on the Istanbul coastal areas, Mar. Geol., 215, 23-43, 2005.

Henry, C., and Das, S.: Aftershocks of large shallow earthquakes: faults dimensions, aftershock area expansion and scaling relations, Geophys. J. Int., 147, 272-293, 2001.

Hornbach, M. J., Braudy, N., Briggs, R. W., Cormier, M.-H., Davis, M. B., Diebold, J. B., Dieudonne, N., Douilly, R., Frohlich, C., Gulick, S. P. S., Johnson, H. E., Mann, P., McHugh, C. M. G., Ryan-Mishkin, K., Prentice, C. S., Seeber, L., Sorlien, C. C., Steckler, M. S., Symithe, S. J., Taylor, F. W., and Templeton, J.: High tsunami frequency as a result of combined strike-slip faulting and coastal landslides, Nat. Geosci., 3, 783-788, 2010.

Hubert-Ferrari, A. 1., Armijo, R., King, G., Meyer, B. and Barka, A.: Morphology, displacement, and slip rates along the North Anatolian Fault, Turkey, J. Geophys. Res., 107, 2235 pp., 2002.

Jet Propulsion Laboratory and University of Southern Carolina, 2013, Moment Magitude Calculator, available at: http: //quakesim.org/tools/moment-magnitude-calculator (last access: 15 February 2014), 2013.

Kanamori, H. and Anderson, D. L.: Theoritical basis of some empirical relations in seismology, Bull. Seismol. Soc. Am., 65, 10731095, 1975.

Ken-Tor, R., Agnon, A., Enzel, Y., and Stein, M.: High-resolution geological record of historic earthquakes in the Dead Sea basin, J. Geophys. Res., 106, 2221-2234, 2001.

Kurt, H., Sorlien, C., Seeber, L., Steckler, M. S., Shillington, D. S., Cifci, G., Cormier, M.-H., Dessa, J.-X., Atgin, O., Dondurur, D., Demirbag, E., Okay, S., Imren, C., Gurcay, S. and Carton, H.: Steady late quaternary slip rate on the Cinarcik section of the North Anatolian fault near Istanbul, Turkey, Geophys. Res. Lett., 40, 4555-4559, doi:10.1002/grl.50882, 2013.

Laigle, M., Becel, A., de Voogd, B. a., Hirn, A., Taymaz, T., and Ozalaybey, S.: A first deep seismic survey in the Sea of Marmara: Deep basins and whole crust architecture and evolution, Earth Planet. Sci. Lett., 270, 168-179, 2008.

Lorenzoni, L., Benitez-Nelson, C. R., Thunell, R. C., Hollander, D., Varelan, R., Astor, Y.,Audemard, F. A., and Muller-Karger, F. E.: Potential role of event-driven sediment transport on sediment accumulation in the Cariaco Basin, Venezuela, Mar. Geol., 105110, doi:10.1016/j.margeo.2011.12.009, 2012

Major, C., Goldstein, S. L., Ryan, W. B. F., Lericolais, G., Piotrowski, A. M., and Hajdas, I.: The co-evolution of Black Sea level and composition through the last deglaciation and its paleoclimatic significance, Quaternary Sci. Rev., 25, 2031-2047, 2006.

Marco, S. and Agnon, A.: Prehistoric earthquake deformations near Masada, Dead Sea graben, Geology, 23, 695-698, 1995. 
McCalpin, J. M.: Paleoseismology. International Geophysics Series, Vol. 95, Academic Press, ISBN: 978-0-12-373576-8, 798 pp., 2009.

McNeill, L. C., Mille, A., Minshull, T. A., Bull, J. M., Kenyon, N. H., and Ivanov, M.: Extension of the North Anatolian Fault into the North Aegean Trough: Evidence for transtension, strain partitioning, and analogues for Sea of Marmara basin models, Tectonics, 3, 1-12, doi:10.1029/2002TC001490, 2004.

Meghraoui, M., Aksoy, M. E., Akyuz, H. S., Ferry, M., Dikbas, A., and Altunnel, E.: Paleoseismology of the North Anatolia Fault at Guzelkoy (Ganos segment, Turkey): Size and recurrence time of earthquake ruptures west of the Sea of Marmara, Geochem. Geophys. Geosys., 13, 1-26, 2012.

McClusky, S., Bassalanian, S., Barka, A., Demir, C., Ergintav, S., Georgiev, I., Gurkan, O., Hamburger, M., Hurst, K., Hans-Gert, H.-G., Karstens, K., Kekelidze, G., King, R., Kotzev, V., Lenk, O., Mahmoud, S., Mishin, A., Nadariya, M., Ouzounis, A., Paradissis, D., Peter, Y., Prilepin, M., Reilinger, R., Sanli, I., Seeger, H., Tealeb, A., Toksöz, M. N., and Veis, G.: Global positioning system constraints on plate kinematics and dynamics in the eastern Mediterranean and Caucasus, J. Geophys. Res., 105, 56955719, 2000.

McHugh, C. M. G., Seeber, L., Cormier, M.-H., Dutton, J., Cagatay, N., Polonia, A., Ryan, W. B. F., and Gorur, N.: Submarine earthquake geology along the North Anatolia fault in the Marmara Sea, Turkey: A model for transform basin sedimentation, Earth Planet. Sci., 248, 661-684, doi:10.1016/j.epsl.2006.05.038, 2006.

McHugh, C., Seeber, L., Braudy, N., Cormier, M.-H., Davis, M. B., Diebold, J. B., Dieudonne, N., Douilly, R., Gulick, S. P. S., Hornbach, M. J., Johnson, H. E. III, Ryan Miskin, K., Sorlien, C., Steckler, M., Symithe, S. J., and Templeton, J.: Offshore sedimentary effects of the 12 January 2010 Haiti earthquake, Geology, 39, 723-726, doi:10.1130/G31815.1, 2011.

McHugh, C., Braudy, N.M., Çağatay, N., Sorlien, C., Cormier, M.H., Seeber, L., and Henry, P.: Sea floor fault ruptures along the North Anatolia Faultin the Marmara Sea, Turkey: Link with the adjacent basin turbidite record, Mar. Geol., 353, 65-83, 2014.

Migeon, S., Weber, O., Faugères, J. C., Saint Paul, J.: A new X-ray imaging system for core analysis, Geomar. Lett., 18, 251-255, 1998.

Moernaut, J.: Sublacustrine landslide processes and their paleoseismological significance: revealing the recurrence rate of giant earthquakes in South-Central Chile, PhD Thesis, University of Ghent, 274 pp., 2011.

Moretti, M., Alfaro, P., Caselles, O., and Canas, J. A.: Modelling seismites with a digital shaking table, Tectonophysics, 304, 369383, 1999.

Nakajima, T. and Kanai, Y.: Sedimentary features of seismoturbidites triggered by the 1983 and older historical earthquakes in the eastern margin of the Japan Sea, Sediment. Geol., 135, 1-19, 2000.

Piper, D. J. W., Cochonat, P., Ollier, G., Le Drezen, E., Morrison, M., and Baltzer, A.: Evolution progressive d'un glissement rotationnel en un courant de turbidité : cas du séisme de 1929 des Grands Bancs (Terre Neuve), Comptes-Rendus de l'Académie des Sciences, Paris, 314, 1057-1064, 1992.

Polonia, A., Gasperini, L., Amorosi, A., Bonatti, E., Bortoluzzi, G., Çağatay, M. N., Capotondi, L., Cormier, M.-H., Görür, N.,
McHugh, C. M. G., and Seeber, L.: Holocene slip rate of the North Anatolian Fault beneath the Sea of Marmara, Earth Planet. Sci.Lett., 227, 411-426, 2004.

Pouderoux, H., Lamarche, G., and Proust, J.-N.: Building an 18 000-year-long paleo-earthquake record from detailed deep-sea turbidite characterisation in Poverty Bay, New Zealand, Nat. Hazards Earth Syst. Sci., 12, 2077-2101, doi:10.5194/nhess-122077-2012, 2012.

Rangin, C., Demirbag, E., Imren, C., Crusson, A., Normand, A., Le Drezen, E., and Le Bot, A.: Marine, Atlas of the Sea of Marmara (Turkey), IFREMER/GENAVIR, 2001.

Reichel, T. and Halbach, P.: An authigenic calcite layer in the sediments of the Sea of Marmara. A geochemical marker horizon with paleoceanographic significance, Deep-Sea Res.II, 54, 1201 1215, 2007.

Reilinger, R. E., McClusky, S., Vernant, P., Lawrence, S., Ergintav, S., Cakmak, R., Ozener, H., Kadirov, F., Guliev, I., Stepanyan, R., Nadariya, M., Hahubia, G., Mahmoud, S., Sakr, K., ArRajehi, A., Paradissis, D., Al-Aydrus, A., Prilepin, M., Guseva, T., Evren, E., Dmitrotsa, A., Filikov, S. V., Gomez, F., Al-Ghazzi, R. and Karam, G.: GPS constraints on continental deformation in the Africa-Arabia-Eurasia continental collision zone and implications for the dynamics of plate interactions, J. Geophys. Res., 111, B05411, doi:10.1029/2005JB004051, 2006.

Rodriguez-Pascua, M.A., Calvo, J.P., De Vicente, G., and GòmezGras, D.: Soft-sediment deformation structures interpreted as seismites in lacustrine sediments of the Prebetic Zone, SE Spain, and their potential use as indicators of earthquake magnitudes during the Late Miocene, Sediment. Geol., 135, 117-135, 2002.

Rodriguez-Pascua, M. A., De Vicente, G., Calvo, J. P., and PerezLopez, R.: Similarities between recent seismic activity and paleoseismites during the late Miocene in the external Betic Chain (Spain): relationship by the $\mathrm{b}$ value and the fractal dimension, J. Struct. Geol., 25, 749-763, 2003.

Ryan, W. B. F., Pitman III, W. C., Major, C. O., Shimkus, K., Moskalenko, V., Jones, G. A. Dimitrov, P., Gorür, N., Sakinc, M., and Yüce, H.: An abrupt drowning of the Black Sea shelf, Mar. Geol., 138, 119-126, 1997.

Ryan, W. B. F. and Pitman III, W. C.: Noah's Flood. The New Scientific Discoveries About Events That Chenged History. Toutchstone Book, Simon \&Schuster Ed., New York, 1999.

Sari, E. and Çağatay, M. N.: Turbidites and their association with past earthquakes in the deep Cinarcik Basin of the Marmara Sea, Geo-Mar. Lett., 26, 69-76, 2006.

Seeber, L., Cormier, M.-H., McHugh, C., Emre, O., Polonia, A., and Sorlien, C.: Rapid subsidence and sedimentation from oblique slip near a bend on the North Anatolian transform fault in the Marmara Sea, Turkey, Geology, 34, 933-936, doi:10.1130/G22520A.1, 2006.

Shillington, D. J., Seeber, L., Sorlien, C. C., Steckler, M. S., Kurt, H., Dondurur, D., Cifici, G., Imren, C., Cormier, M.-H., McHugh, C. M. G., Gurcay, S., Poyraz, D., Okay, S., Atgin, O., and Diebold, B.: Evidence for widespread creep on the flanks of the Sea of Marmara transform basin from marine geophysical data, Geology, 40, 439-442, doi:10.1130/G32652.1, 2012

Siegenthaler, C., Finger, W., Kelts, K., and Wang, S.: Earthquake and seiche deposits in Lake Lucerne, Switzerland, Eclogae Geolog. Helvetiae, 80, 241-260, 1987. 
Sims, J.: Determining earthquake recurrence intervals from deformational structures in young lacustrine sediments, Tectonophysics, 29, 141-152, 1975.

Strasser, M., Anselmetti, F. S., Fäh, D., Giardini, D., and Schnellmann, M.: Magnitudes and source areas of large prehistoric northern Alpine earthquakes revealed by slope failures in lakes, Geology, 34, 1005-1008, 2006.

Tary, J. B., Géli, L., Guennou, C., Henry, P., Sultan, N., Cagatay, N., and Vidal, V.: Microevents produced by gas migration and expulsion at the seabed: a study based on sea bottom recordings from the Sea of Marmara, Geophys. J. Int., 190, 993-1007, 2012.

Thunell, R., Tappa, E., Valera, R., Llano, M., Astor, Y., MullerKarger, F., and Bohrer, R.: Increased marine sediment suspension and fluxes following an earthquake, Nature, 398, 233-236, 1999.

Toksöz, M. N., Shakal, A. F., and Michael, A. J.: Space-time migration of earthquakes along the North Anatolian fault zone and seismicity gaps, Pure Appl. Geophys., 924, 1258-1270, 1979.

Uçarkuş, G.: Active faulting and earthquake scarps along the North-Anatilian Fault in the Sea of Marmara. PhD Thesis, ITU, Eurasian Institute of Earth Sciences, Istanbul, 173 pp., 2010.
Uçarkuş, G., Çakır, Z., and Armijo, R.: Western Termination of the Mw 7.4, 1999 Izmit Earthquake Rupture: Implications for the Expected Large Earthquake in the Sea of Marmara, Turkish J. Earth Sci., 20, 379-394, doi:10.3906/yer-0911-72, 2011.

Vidal, L., Menot, G., Joly, C., Bruneton, H., Rostek, F., Çağatay, N, Major, C., and Bard, E.: Hydrology in the Sea of Marmara during the last $23 \mathrm{ka}$ : Implications for timing of Black Sea connections and sapropel deposition, Paleoceanography, 25, PA1205, doi:10.1029/2009PA001735, 2010.

Wetzler, N., Marco, S., and Heifetz, E.: Quantitative analysis of shear-induced turbulence in lake sediments, Geology, 38, 303306, 2010.

Zitter, T., Grall, C., Henry, P., Özeren, M. S., Çağatay, M. N., şengor, A. M. C., Gasperini, L., Mercier de Lépinay, Géli, L.: Distribution, morphology and triggers of submarine mass wasting in the Sea of Marmara, Mar. Geol., 329/331, 58-74, 2012. 